\title{
Szemelvények a katonai víztisztítási kutatásokból (az 1970-es és '80-as években), különös tekintettel a fordított ozmózis alkalmazására n.resz
}

\section{BeVEzetés}

Magyarországon az 1970-es és '80-as években, mintegy 15 éven keresztül, nagyszabású kutató- és fejlesztő munka folyt a HTI vezetésével a katonai víztisztítás témakörében. A fő cél egy $4 \mathrm{~m}^{3} / \mathrm{h}$ teljesítményű tábori, katonai víztisztító berendezést is tartalmazó, ún. mobil „Ezred Vízközpont” (EVK) létrehozása volt.

A kutatómunka alapvetően a komplex katonai víztisztítási technológia résztechnológiáinak (lásd 1. ábra) összeállítására, a követelményeknek megfelelő bevizsgálására terjedt ki, de számos egyéb - menet közben felmerült - részfeladatot is meg kellett oldani.

A szennyezett víz minden egyes szennyező anyagára, amelyek katonailag reálisan figyelembeveendők országonként, illetve szövetségi rendszerenként elfogadott (becsült) paramétereket határoztak meg. Nyersvízként általában a felszíni vizek (beleértve a tengervizet is) jöhetnek szóba.

Az iható víz paraméterei hasonlóképpen elfogadottak, az egyes anyagokra szigorúan elöírtak és megköveteltek. Itt egy további megszorítás, hogy rendelkezni kell az egyes reális szennyezőanyag-koncentrációk ihatósági szintjének megfelelő érzékenységű kimutatási módszerrel! (Minimum a kutatás-fejlesztés, illetve a víztisztítási technológia ellenőrzése időszakában.) Mivel a nyersvíz egy-egy szennyező

ÖSSZEFOGLALÁS: Magyarországon az 1970-es és '80-as években jelentős haditechnikai kutatási és fejlesztési feladatok végrehajtása folyt a katonai víztisztítás területén, az akkori Haditechnikai Intézet vezetésével. Ennek során speciális vizsgálatokkal ellenőrzésre került többek között a fordított ozmózis alkalmazhatósága is. Az akkori nemleges döntés a fordított ozmózissal kapcsolatban a kezdeti vizsgálati eredmények és a magyar ipari lehetőségek figyelembevételével került meghozatalra. A cikk végén rövid áttekintést adunk a mai helyzetről.

KULCSSZAVAK: komplex katonai víztisztítás, ozmózis, fordított ozmózis (F0), FO modulok, a víz ABV mentesítése, ZENON víztisztító anyagra vonatkozó koncentrációja (általában $\mathrm{mg} / \mathrm{dm}^{3}$ ) nagyságrendekkel magasabb, mint az iható vízben megengedett koncentráció, könnyen belátható, hogy ez egy igen szigorú követelmény. Az iható vízben néhány anyag esetén $10^{-4}-10^{-6} \mathrm{mg} / \mathrm{dm}^{3}$ anyagmennyiség biztonságos mérése válik szükségessé. (Ezekben az esetekben az alsó méréshatár tekintetében további igen szigorú követelményeknek kell megfelelni.)

A müszaki fejlesztési feladat pedig az akkor még nem létező eszközök (a komplett víztisztító, és az EVK néhány részegysége, lásd később az EVK felépítése résznél) prototípusainak az előállítását és mindenoldalú vizsgálatait tartalmazta.

A feladat megvalósításában résztvevő irányító szervek, intézmények és vállalatok az 1 . táblázatban kerültek összefoglalásra (az akkori megnevezéseikkel), és - a teljesség igénye nélkül - a témánkat illető főbb feladataikkal. (A kutatás és a műszaki fejlesztés végrehajtásában - itt most nem részletezett - átfedések is voltak a kutatóintézetek és a gyártó vállalatok között.)

A cél megvalósult, az eredményes haditechnikai ellenörző vizsgálatok és a csapatpróba után a víztisztító berendezést az akkori PVOP rendszeresítette, majd, a 0-sorozati példányokat kiadta az OVH néhány vízmüvének felhasználásra.

ABSTRACT: In the 1970s and '80s, significant research and developement has been carried out in the area of military water purification in Hungary, lead by the HTI on the time. As part of this effort, among others, specific research methods verified the possible application of reverse osmosis. The decision at the time regarding the use of reverse osmosis was based on the early research results and the realities of the hungarian industry. At the end of the article, we give a short overview of the present-day situation.

KEY WORDS: complex military water purification, osmosis, reverse osmosis (RO), RO modules, NBC decontamination, ZENON water purifier

* A HTI nyugállományú főigazgatója, nyá. mk. ezds, okleveles gépészmérnök, okleveles gazdasági mérnök. A vizsgált időszakban - többek között - a katonai vízellátás HTI témafelelőse. E-mail: gerleis@chello.hu.

Retired General Director of HTI, Master's in Mechanical Engineering, Master's in Economy Engineering. Was in charge of military water supply, among other things, in the examined period.

** A HTI nyugállományú főtanácsosa, okleveles gépész üzemmérnök. A vizsgált időszakban munkatárs a témában. A ZENON víztisztítóval kapcsolatos HTI feladatok témafelelőse. E-mail: - Retired chief advisor of HTI. Master's in Production Engineer. Worked on the topic in the examined period. Was in charge of $\mathrm{HTI}$ tasks related to ZENON water purrifier.

*** Okleveles vegyészmérnök, a NEVIKI volt munkatársa. A vizsgált időszakban a NEVIKI egyik témafelelőse a komplex katonai víztisztítás területén. E-mail: - Master's in Chemical Engineering, was an employee of NEVIKI, currently retired. Was in charge at NEVIKI in the area of complex military water purification in the examined period. 


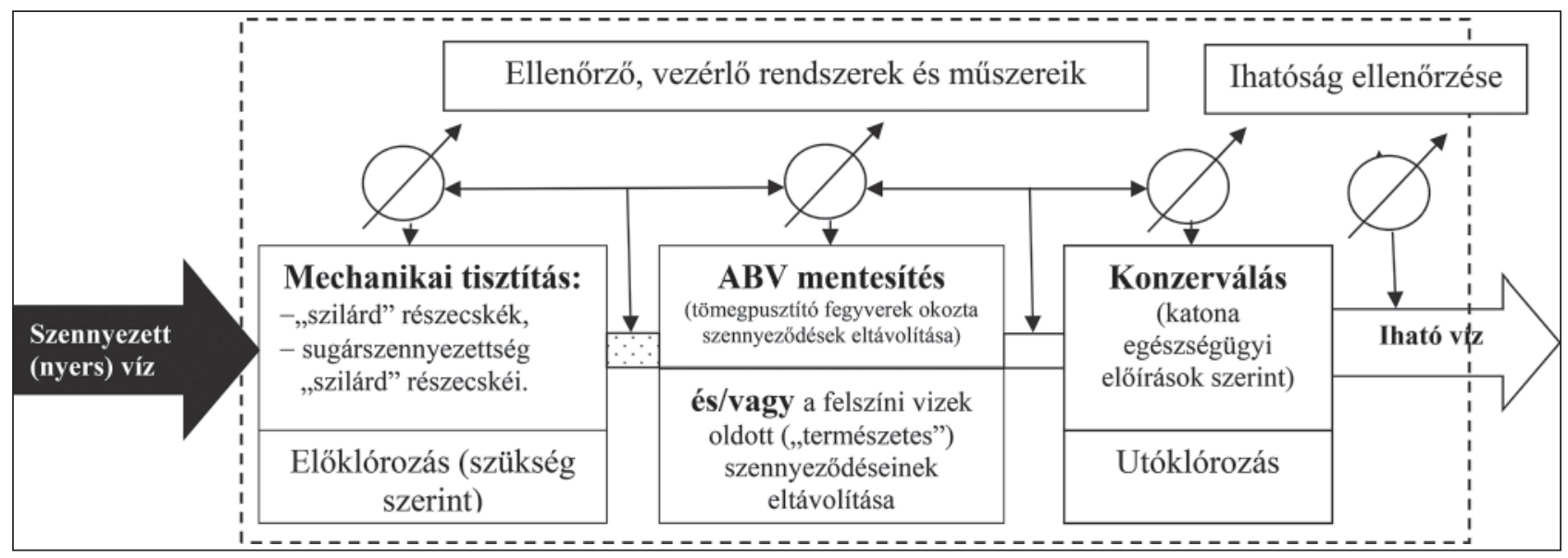

1. ábra. A komplex katonai víztisztítás elvi vázlata

Az 1970-es években megjelent néhány kapcsolódó cikk, mintegy „népszerűsítve” a témát. Ezek közül hármat említünk, (lásd irodalomjegyzék) mert a jelen cikk 1. ábrájához és a későbbi alapfogalmak részéhez, azok egyes részeit átdolgozva forrásanyagként használtuk. [1. 2. és 3.]

A vizsgált időszakban a feladatok végrehajtásának számos fontos és elengedhetetlen mellékszála is volt. llyenek voltak (a teljesség igénye nélkül), pl.:

- A víztisztító csapateszközök egységes vizsgálati metodikájának (EVM) kidolgozása (hétoldalú + EFE TT5 nemzetközi katonai együttmüködés keretében). Ennek során új analitikai módszerek kidolgozása is szükségessé vált, (ahol az alsó méréshatár addig nem volt megfelelő). Összefogó: HTI. A feladat eredményesen végrehajtva. Az EVM-t az EFE TT a tagországok több éves kidolgozói munkája után ún. ideiglenes munkacsoport-ülésen (IMCS) elfogadta és jóváhagyta.

- Atombomba robbanás okozta sugárszennyezettség szilárd részecskéinek modellezése, valamint a korábbi „Szovjet" módszer gyakorlati kritikája. Kidolgozó: NEVIKI. A feladat eredményesen végrehajtva. A NEVIKI módszere egy változatként bekerült az EVM-be.

- Háromoldalú nemzetközi együttműködés (csehszlovák-német-magyar) keretében a fordított ozmózist (is) alkalmazó víztisztító harcászati müszaki követelményeinek (HMK) az összeállítása. Összefogó: HTI. A feladat eredményesen végrehajtva, a felek jóváhagyták a közösen kidolgozott HMK-t.

- A megvalósult víztisztítóval kapcsolatban több szabadalom is kidolgozásra került, többek között a szerzők közreműködésével. (Lásd [10.])

\section{Az EVK Fő RÉSZEKÉNT KIFEJLESZTETT MOBIL VízTISZTító BERENDEZÉs (MVT-4) RöVID BEMUTATÁSA}

A komplett EVK-val a jelen cikkben csak annyiban foglalkozunk, hogy - a főbb részeinek felsorolása után - megadjuk a 2. ábrában és a hozzátartozó jelmagyarázatban a telepítési vázlatát. (Lásd a 2. ábrát.)

Az EVK felépítése, illetve főbb részei:

- $2 \mathrm{db}$ konténer kereszttartós, 5 t terepterhelhetőségü szállító jármű.

- 2 db KF-3 típusú zárt felépítmény a katonai felépítmények alapfelszereléseivel (katonai szűrő-szellőző, fűtőkészülék, belső világítás, elektromos csatlakozó- és kapcsolószekrény, akkumulátorok, akkumulátortöltő stb.).
- 1 db HAD típusú áramforrás aggregát (3 fázis, 20 kVA).

- 1 klt. víztisztító berendezés, (MVT-4) - új fejlesztés.

- 1 klt. nagy emelőmagasságú, a felszíni vizekre telepíthető úszó, búvárszivattyús vízkiemelő eszköz - új fejlesztés (az MVT-4 részeként).

- $1 \mathrm{db}$ tömlőmentesítő, tisztító berendezés - új fejlesztés (az MVT-4 részeként)

- Nyomótömlő klt. a nyersvízhez.

- Fogyóanyag-készlet min. 80 üzemóráig elegendő, (perlit, aktív szenek, ioncserélő mügyanta stb.).

- 12 db összehajtható (flexibilis), zárt víztároló (1 500 $\mathrm{dm}^{3} / \mathrm{db}$ ) - új önálló fejlesztés

- 1 klt. tábori vegyi laboratórium (TVL-68).

- 1 klt. sugár-felderítő és -mérő műszer.

- $1 \mathrm{db}$ klórgázpalack (külön, zárt fülkében), ADVANCE klórgáz adagolóval.

- 1 klt. előklórozó.

- 1 klt. utóklórozó.

- A személyzet egyéni vegyivédelmi felszereléseinek a helye.

- Javító eszközök és szerszámok.

- Álcaháló klt.

Az MTV-4 víztisztító föbb adatai:

- Teljesítmény: $\quad 4 \mathrm{~m}^{3} / \mathrm{h}$ (ABV szennyezés

- Kezelőszemélyzet: telepítéskor 4-5 fő,

- Telepítési idő:

- Üzemi hőmérséklet: víz: $274-303 \mathrm{~K}\left(+1{ }^{\circ} \mathrm{C}\right.$-tól + folyamatos üzemben 2 fő. 45 min.

$\left.30{ }^{\circ} \mathrm{C}-\mathrm{ig}\right)$.

környezet: 248-323 K (- 25

${ }^{\circ} \mathrm{C}$-tól $+50{ }^{\circ} \mathrm{C}$-ig).

- Vezérlés: automatikus, külön kezelőpultról beállítva a részfolyamatokat.

- Tárolható tisztított víz: a felépítményen kívül 12×1,5 m³, az EVK B felépítményben: $1 \mathrm{~m}^{3}$.

A rendszer készletezése olyan volt, hogy a víztisztító berendezés önállóan is alkalmazható legyen. Ezért többek között a víztisztítót tartalmazó felépítményt szállító jármű vontatta az áramforrás aggregátot.

Az MVT-4 által megvalósított technológia összefoglalóan - és követve az 1. ábrán bemutatott elveket - a következő volt:

a) Lebegő (szilárd, mechanikai) szennyeződések eltávolítása (hidrociklon-telep alkalmazásával és ún. ráiszapoló/,bemosó”, felrétegező/ szűréssel).

b) Oldott (ipari, mezőgazdasági, kommunális) szennyeződések, valamint a tömegpusztító fegyverek (ABV) 
1. táblázat. A hazai katonai víztisztítási K+F feladatok megvalósításában résztvevő szervezetek 1970-1985 között

\begin{tabular}{|c|c|c|c|}
\hline \multicolumn{2}{|r|}{ Megnevezés } & $\begin{array}{c}\text { Fỏbb feladatok a vizsgált témát } \\
\text { illetően }\end{array}$ & Példák a feladatokból \\
\hline \multirow{4}{*}{$\begin{array}{l}\text { Irányító } \\
\text { szervek }\end{array}$} & $\begin{array}{l}\text { MNVK Anyagtervezési } \\
\text { CsFség }\end{array}$ & \multirow{2}{*}{$\begin{array}{l}\text { Az alárendelt területek feladatainak } \\
\text { anyagi, pénzügyi, szakmai tervezése, } \\
\text { ellenőrzése. }\end{array}$} & \\
\hline & $\begin{array}{l}\text { MNVK Haditechnikai } \\
\text { CsFség }\end{array}$ & & $\begin{array}{l}\text { Csapatpróba eredmények } \\
\text { értékelése. } \\
\text { HMK jóváhagyás. }\end{array}$ \\
\hline & $\begin{array}{l}\text { KGM Általános Szervezési } \\
\text { Főosztály }^{1}\end{array}$ & $\begin{array}{l}\text { Az alárendelt vállalatok feladatainak } \\
\text { tervezése, ellenőrzése. }\end{array}$ & \\
\hline & $\begin{array}{l}\text { Országos Vízügyi Hivatal } \\
(\mathrm{OVH})\end{array}$ & $\begin{array}{l}\text { Az alárendelt szervezetek } \\
\text { feladatainak tervezése, ellenőrzése. }\end{array}$ & $\begin{array}{l}\text { Vízvizsgáló laboratóriumok } \\
\text { biztosítása a haditechnikai ellenőrző } \\
\text { vizsgálatokhoz }{ }^{2}\end{array}$ \\
\hline \multirow{4}{*}{$\begin{array}{l}\text { Egyéb } \\
\text { érintett } \\
\text { katonai } \\
\text { szerve- } \\
\text { zetek }\end{array}$} & $\begin{array}{l}\text { MN Egészségügyi } \\
\text { Szolgálat Főnökség }\end{array}$ & \multirow{4}{*}{$\begin{array}{l}\text { Az alárendelt területek feladatainak } \\
\text { anyagi, pénzügyi, szakmai tervezése, } \\
\text { ellenőrzése. }\end{array}$} & \multirow{2}{*}{$\begin{array}{l}\text { Egyetértés a HMK-kal. } \\
\text { A tisztított víz ihatóságának a } \\
\text { meghatározása. } \\
\text { Csapatpróba-közreműködés. }\end{array}$} \\
\hline & $\begin{array}{l}\text { MN Közegészség- és } \\
\text { Járványügyi Állomás }\end{array}$ & & \\
\hline & MN Műszaki Főnökség & & \multirow{2}{*}{$\begin{array}{l}\text { Egyetértés a HMK-kal. } \\
\text { Csapatpróba-tervezés. } \\
\text { Csapatpróba eredmények értékelése. } \\
\text { Rendszeresítés előkészítése }\end{array}$} \\
\hline & $\begin{array}{l}\text { Polgári Védelem Országos } \\
\text { Parancsnokság }\end{array}$ & & \\
\hline $\begin{array}{l}\text { Szakmai } \\
\text { összefogó } \\
\text { és téma- } \\
\text { felelős }\end{array}$ & $\begin{array}{l}\text { HTI: } \\
\text { - Múszaki- és hadtáp } \\
\text { technikai osztály } \\
\text { - Vegyivédelmi osztály } \\
\text { - Anyagvizsgáló és } \\
\text { kísérleti múhely }\end{array}$ & $\begin{array}{l}\text { A haditechnikai K+F feladatok } \\
\text { tervezése, a végrehajtás irányítása és } \\
\text { szervezése. } \\
\text { Követelményrendszerek kidolgozása } \\
\text { témánként (HMK-k). } \\
\text { A haditechnikai ellenőrző vizsgálatok } \\
\text { tervezése, szervezése és } \\
\text { végrehajtása. }\end{array}$ & $\begin{array}{l}\text { Éves és több éves tervek. } \\
\text { Haditechnikai K+F³ szerződések. } \\
\text { HMK-k kidolgozása. } \\
\text { Vizsgálati tervek. } \\
\text { Vizsgálati javaslatok a } \\
\text { csapatpróbákhoz. } \\
\text { Csapatpróba eredmények } \\
\text { értékelése. } \\
\text { Kísérleti eszközök készítése. }\end{array}$ \\
\hline \multirow[t]{3}{*}{$\begin{array}{l}\text { Kutató } \\
\text { intézetek }\end{array}$} & $\begin{array}{l}\text { Nehézvegyipari Kutató } \\
\text { Intézet (NEVIKI) }\end{array}$ & $\begin{array}{l}\text { A Haditechnikai K+F feladatok } \\
\text { végrehajtása a komplex } \\
\text { tématerületen. } \\
\text { A víztisztítási résztechnológiák és } \\
\text { anyagainak kidolgozása. } \\
\text { Vizsgálatok, speciális analitikai } \\
\text { mérések. } \\
\text { Prototípusok tervezése és gyártása. }\end{array}$ & $\begin{array}{l}\text { Ún. „kis-minta”, majd üzemi-minta } \\
\text { mérések. (Hasonlósági elvek } \\
\text { betartása!) } \\
\text { Speciális szorbens anyagok } \\
\text { létrehozása. } \\
\text { A víz ABV „tisztítása”, vegyi } \\
\text { harcanyagok analitikai mérései. } \\
\text { A víztisztító prototípus gyártása. } \\
\end{array}$ \\
\hline & $\begin{array}{l}\text { Központi Élelmiszer- } \\
\text { Tudományi Kutatóintézet } \\
\text { (KÉKI) }\end{array}$ & $\begin{array}{l}\text { Ht. K+F feladatok végrehajtása a } \\
\text { fordított ozmózissal kapcsolatban. }\end{array}$ & $\begin{array}{l}\text { Cellulóz-acetát sík membránok } \\
\text { készítése és „polgári” vizsgálata. } \\
\text { Kísérleti berendezések készítése. }\end{array}$ \\
\hline & $\begin{array}{l}\text { Vízgazdálkodási } \\
\text { Tudományos Kutató } \\
\text { Intézet (VITUKI) }\end{array}$ & $\begin{array}{l}\text { Részvétel az egyes víztisztítási } \\
\text { résztechnológiák kidolgozásában. }\end{array}$ & $\begin{array}{l}\text { A víz mechanikai tisztítása. } \\
\text { Részvétel a haditechnikai ellenőrző } \\
\text { vizsgálatokban. }\end{array}$ \\
\hline \multirow{4}{*}{$\begin{array}{l}\text { Gyártó } \\
\text { vállalatok }\end{array}$} & Graboplast & $\begin{array}{l}\text { Részvétel egyes kiegészítő eszköz } \\
\text { fejlesztésében és gyártásában. }\end{array}$ & 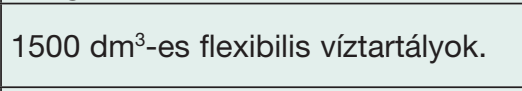 \\
\hline & $\begin{array}{l}\text { Labor Műszeripari Művek } \\
\text { (LMIM) }\end{array}$ & Katonai felépítmények gyártása. & $\begin{array}{l}\text { Konténerszerű }\left(\mathrm{KF}^{4}\right) \text { felépítmények } \\
\text { gyártása. }\end{array}$ \\
\hline & $\begin{array}{l}\text { Nyergesújfalui Viscosa } \\
\text { Gyár }\end{array}$ & Üreges szálak gyártása. & \\
\hline & $\begin{array}{l}\text { Vízgépészeti Vállalat } \\
\text { (VÍZGÉP) }\end{array}$ & 0-sorozat gyártás. & \\
\hline Egyéb & $\begin{array}{l}\text { OVH alárendeltségében } \\
\text { lévő vízművek vízvizsgáló } \\
\text { laboratóriumai }\end{array}$ & $\begin{array}{l}\text { Vízvizsgáló laboratóriumok kijelölése } \\
\text { és biztosítása: Balatonfüred, } \\
\text { Dunaújváros, Szolnok, Szeged, } \\
\text { Mohács, Sajóecseg és a Lázbérci } \\
\text { víztározó vízműveitől. }\end{array}$ & $\begin{array}{l}\text { A nyersvíz és a tisztított víz } \\
\text { vizsgálata a haditechnikai ellenőrző } \\
\text { vizsgálatokon, illetve a } \\
\text { csapatpróbán. }\end{array}$ \\
\hline
\end{tabular}




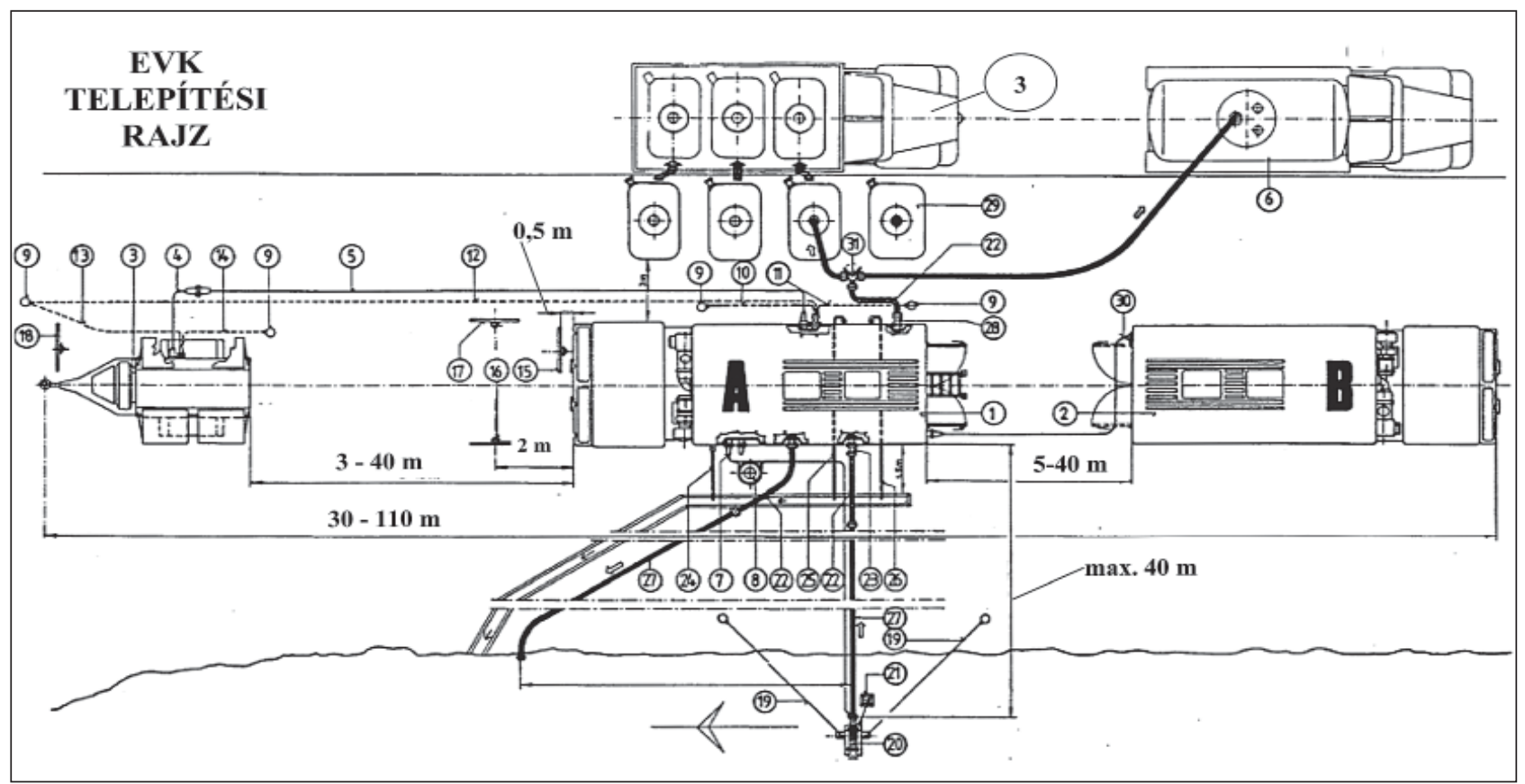

\section{2. ábra. Az Ezred Vízközpont ajánlott telepítése}

1. MVT-4 az EVK „A” járművén, ill. felépítményében; 2. EVK „B” felépítmény; 3. Áramforrás: aggregát; 4. Tápkábel csatlakozó közdarab; 5. Tápkábel; 6. Vízszállító tj. tgk. (Nem része az EVK-nak.); 7. Nyersvíz szivattyú tápkábel; 8. Kábeldob a nyersvíz szivattyúhoz; 9. Földelő nyársak; 10. Földelő vezeték „GÉPTEST”; 11. Földelő vezeték „SZIGETELT 0”; 12. Földelő vezeték „SEGÉDFÖLD”; 13. Földelö vezeték „AGGREGÁT SEGÉDFÖLD”; 14. Földelö vezeték „AGGREGÁT”; 15. Jelzőtábla „VíZKÖZPONT”; 16. Jelzőtábla „SZENNYEZETT TÉRFÉL”; 17. Jelzőtábla „TISZTA TÉRFÉL”; 18. Jelzőtábla „ÜZEMI TERÜLET”;

19. Rögzítőkötél a vízkiemelőhöz; 20. Búvárszivattyús nyersvíz kiemelő egység; 21. Horgony; 22. Csigatömlő́k; 23. Visszacsapó szelep; 24. Légtelenítő vezeték 8 . sz. oszlop; 25 . Légtelenítő vezeték 9 . sz. oszlop; 26. Légtelenító vezeték 10 . sz. oszlop; 27. Nyomótömlök; 28. Közdarab (2"- C jelü csonkkapocs); 29. 1500 dm³-es zárt víztartályok; 30. Összekötő kábel; 31. Váltócsap; 32. Zárt víztartály-szálító tj. tgk. (Nem része az EVK-nak.)

okozta szennyeződések eltávolítása (adszorpció és ioncsere segítségével).

c) Biológiai anyagok eltávolítása („csírátlanítás”), illetve a tisztított víz konzerválása (előkészítése szállításra) klóro- zással (klórgáz adagolással). Intenzív előklórozás (ha szükséges) a mechanikai szürés előtt, utóklórozás a víz kiadása előtt. Az előklórozást követő deklórozás a mechanikai tisztítás utáni aktív szén töltetű oszlopban történt.

3. ábra. Az MVT-4 folyamatábrája

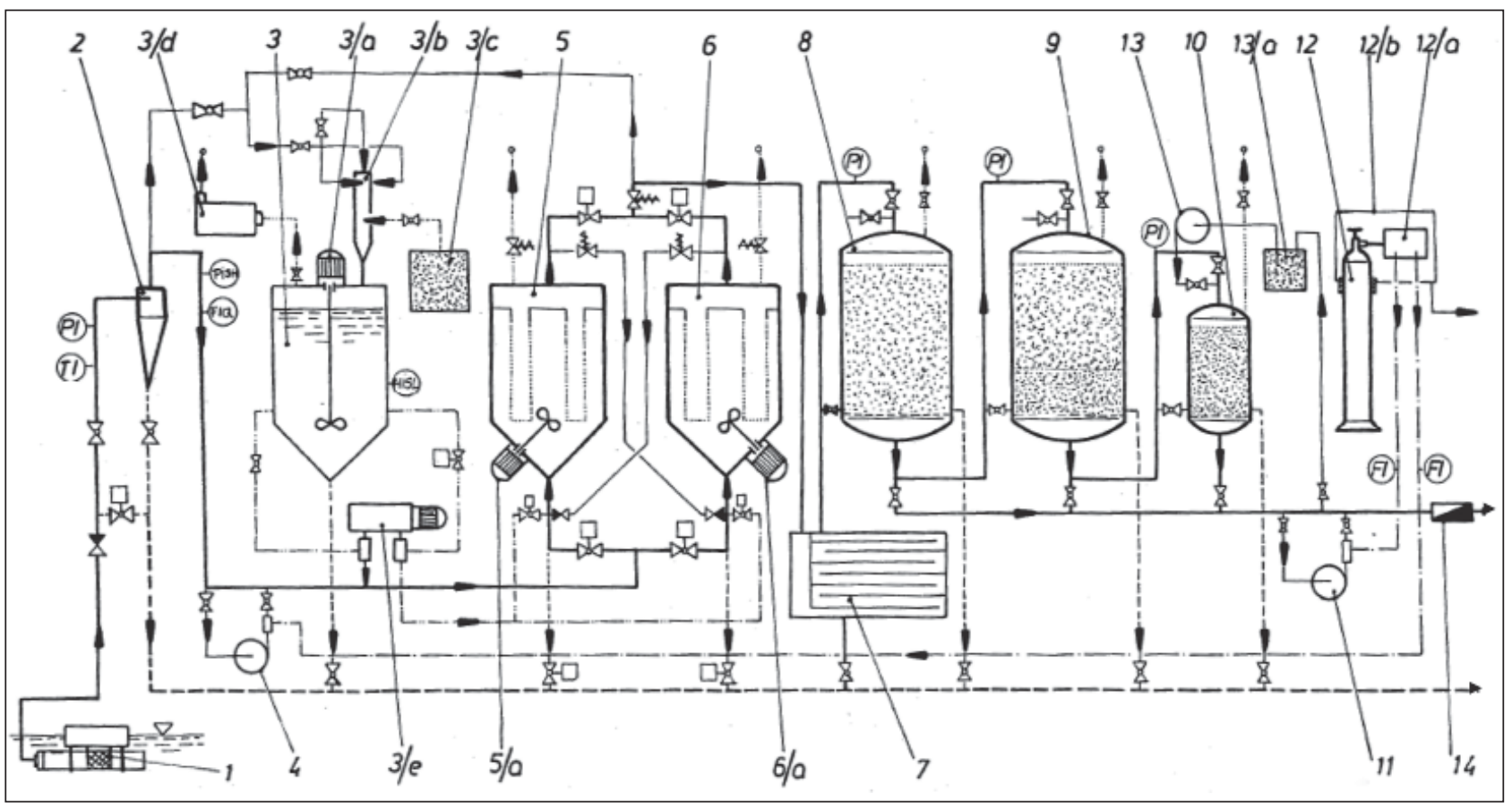


2. táblázat. A 3. ábra jelmagyarázata: Az MVT-4 technológiai folyamatai

\begin{tabular}{|c|c|c|c|c|}
\hline \multicolumn{2}{|r|}{ A technológiai elem } & \multirow{2}{*}{$\begin{array}{l}\text { Vízáramok jele, } \\
\text { megnevezése }\end{array}$} & \multirow{2}{*}{$\begin{array}{l}\text { Mérőmúszerek jele, } \\
\text { megnevezése }\end{array}$} & \multirow{2}{*}{$\begin{array}{l}\text { Kezelő elemek jele, } \\
\text { megnevezése }\end{array}$} \\
\hline száma & megnevezése & & & \\
\hline 1. & $\begin{array}{l}\text { Búvárszivattyús, úszó } \\
\text { vízkiemelő }\end{array}$ & \multirow{4}{*}{$\begin{array}{l}\text { Fő tech- } \\
\text { nológiai } \\
\text { vízáram }\end{array}$} & \multirow{4}{*}{ Nyomás } & \multirow{4}{*}{ Gömbcsap } \\
\hline 2. & Hidrociklon telep & & & \\
\hline 3. & Perlit bekeverő & & & \\
\hline 3/a. & Keverő & & & \\
\hline 3/b. & Perlit nedvesítő & \multirow{4}{*}{$\begin{array}{l}\text { Hulladék } \\
\text { víz }\end{array}$} & \multirow{4}{*}{$\begin{array}{l}\text { Hőmér- } \\
\text { séklet }\end{array}$} & \multirow{8}{*}{ Möoros } \\
\hline $3 / c$. & Perlit tároló & & & \\
\hline $3 / d$. & Porszívó & & & \\
\hline $3 / e$. & Adagoló (perlit szuszpenzió) & & & \\
\hline 4. & Előklórozó & \multirow{4}{*}{$\begin{array}{l}\text { Mellék } \\
\text { vízáram }\end{array}$} & \multirow{4}{*}{$\begin{array}{l}\text { Klór- } \\
\text { mennyiség }\end{array}$} & \\
\hline 5. & Mechanikai szűrő I. & & & \\
\hline 5/a. & Keverő & & & \\
\hline 6. & Mechanikai szűrő II. & & & \\
\hline 6a. & Keverő & \multirow{4}{*}{$\begin{array}{l}\text { Perlit } \\
\text { szusz- } \\
\text { penziózió }\end{array}$} & \multirow{4}{*}{$\begin{array}{l}\text { Nyersvíz } \\
\text { mennyiség, } \\
\text { összegzés }\end{array}$} & \multirow{4}{*}{$\begin{array}{l}\text { Mágnes } \\
\text { szelep }\end{array}$} \\
\hline 7. & \begin{tabular}{|l} 
Csőkígyó (a klór \\
hatásidejének a növelésére)
\end{tabular} & & & \\
\hline 8. & „A” oszlop (aktív szén) & & & \\
\hline 9. & $\begin{array}{l}\text { „B” oszlop (kétféle } \\
\text { impregnált aktív szén) }\end{array}$ & & & \\
\hline 10. & $\begin{array}{l}\text { "C" oszlop (kevertágyas } \\
\text { ioncserélő műgyanta) }\end{array}$ & \multirow{4}{*}{ — Klórgáz } & \multirow{4}{*}{ Nyersvíz } & \multirow{4}{*}{$\begin{array}{l}\text { Visszacsapó } \\
\text { szelep }\end{array}$} \\
\hline 11. & Utóklórozó & & & \\
\hline 12. & Klórgáz-palack & & & \\
\hline 12/a. & Klórgáz adagoló & & & \\
\hline 12/b. & Klórgáz-vezeték & \multirow{4}{*}{$\bullet \bullet \bullet \bullet \bullet \bullet$ Levegő } & \multirow{4}{*}{ serlit } & \multirow{4}{*}{$\begin{array}{l}\text { Mennyiség } \\
\text { mérő }\end{array}$} \\
\hline 13. & $\begin{array}{l}\text { Töltet betöltő szivattyú az } \\
\text { oszlopokhoz }\end{array}$ & & & \\
\hline 13/a. & Töltettároló az oszlopokhoz & & & \\
\hline 14. & Vízóra & & & \\
\hline
\end{tabular}

A fenti víztisztítási résztechnológiák közül, a nyersvíz szennyeződéseitől függően, választhattunk az egyes technológiai lépcsők között. Az egyes tisztítási fázisok elhagyásához megkerülő csővezetékek voltak beépítve.

A berendezésbe épített elektronika az indulás után teljesen automatikus üzemet biztosított. Folyamatosan ellenőrizhetők a fontosabb nyomásértékek, a kilépő víz mennyisége, és a klóradagolás. Az egyes részegységek szűrési segédanyagai, illetve töltetei zárt (pneumatikus és hidraulikus) segédrendszerek segítségével szálíthatók a szűrőkbe, illetve az oszlopokba, ahonnan elhasználódás után zagy formájában üríthetők le.

A víztisztítás technológiáiát részleteiben a 3 . ábrán és a hozzá tartozó jelmagyarázatot tartalmazó 2. táblázat segítségével tanulmányozhatjuk. (Lásd a 3. ábrát.) A KF-3 felépítménybe épített MVT-4 berendezés egy részletét pedig a 4. ábra mutatja.

$10 \rightarrow$ HADITECHNIKA LI. évf. - 2017/4
4. ábra. A KF-3 katonai felépítménybe épített MVT-4 berendezés

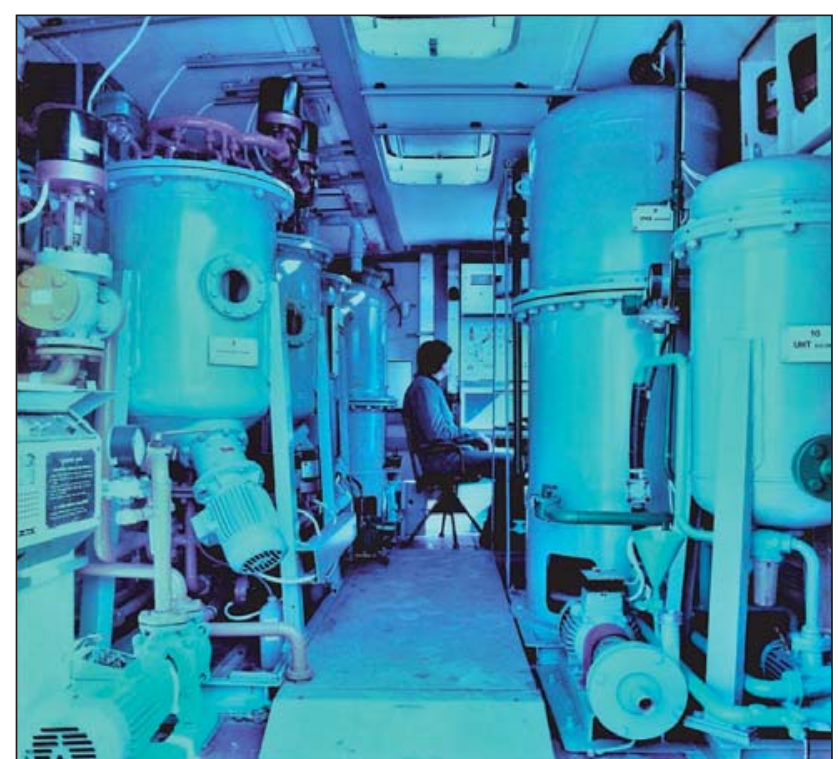




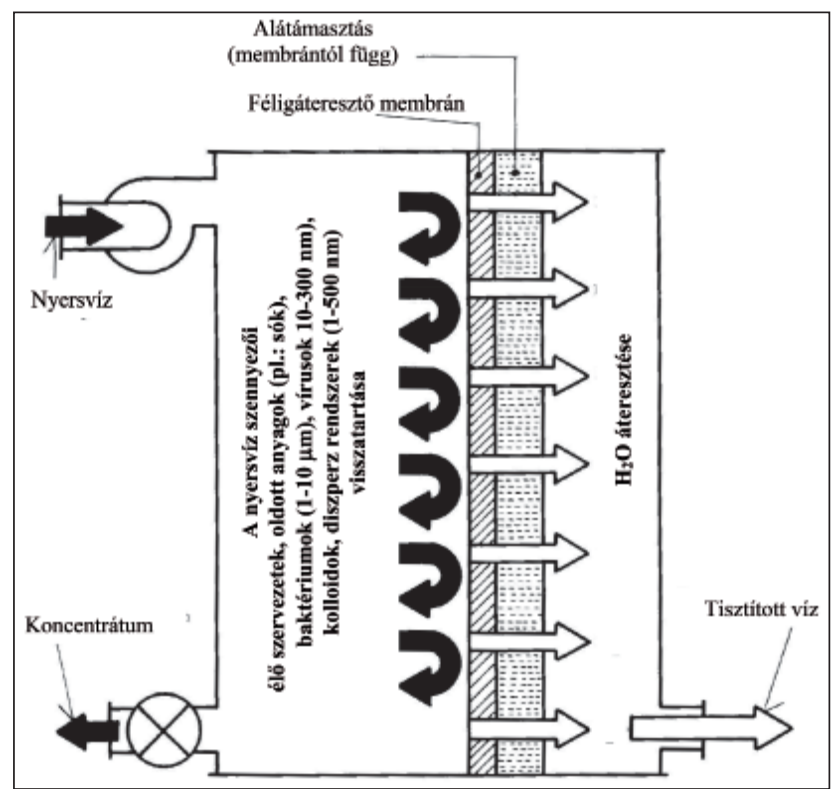

8. ábra. Elméleti víztisztítási lehetőségek a fordított ozmózis alkalmazásával

A membránok főbb jellemzői:

- vízáteresztés,

- oldott anyag (só) áteresztés,

- visszaverődés.

Az elvi víztisztítási lehetőségeket az FO-val a 8. ábrán szemléltetjük.

A gyakorlati tisztítási lehetőségeket, és főleg a tisztított víz oldali eredményeket, az eddig vázlatosan tárgyalt alapok mellett azonban számos - itt most nem részletezett tényező is befolyásolja, különösen a tömegpusztító fegyverek okozta szennyeződések (és ezen belül, főleg a vegyi harcanyagok) eltávolítása terén.

A milliméter alatti tartományokban (lásd 9. ábra) való eligazodáshoz a [5.] jelü forrásanyagban található ábra egy részébe beillesztettük a 8 . ábrán említett tartományokat.

\section{(Folytatjuk)}

\section{IRODALOMJEGYZÉK}

[1.] Gerlei István: A komplex víztisztítás és a fordított ozmózis. Haditechnika. 1975. 2 sz. 41-46. oldal.;

[2.] Gerlei István, Dr. Vasvári Vilmos: A víztisztítás eszközei. Honvédelem.1978.;

\section{JEGYZETEK} eredményei alapján történt a csapatpróbára felajánlás a HTI részéről.

$3 \mathrm{Ht}$. $\mathrm{K}+\mathrm{F}=$ haditechnikai kutatás és műszaki fejlesztés.
[3.] Dr. Dobolyi Elemér - Dobos Ferencné: A fordított ozmózis elvének gyakorlati alkalmazása a vízgazdálkodásban. Hidrológiai Közlöny. 1978. 3. sz. 122-130. oldal.;

[4.] Kéziratok: Dr. Demeczky Mihály, Khell Ádámné (KÉKI), Dr. Pernyeszi József (NEVIKI), Gerlei István (HTI)

Melenyec János (HTI) korabeli kéziratai, néhány esetben szó szerint kézzel írva.;

[5.] http://enfo.agt.bme.hu/drupal/sites/default/ files/737px-Relative_scale_hu.svg_.png

[6.] Kállai Ernő - Padányi József: Új víztisztító berendezés a Magyar Honvédségben. Haditechnika. 2005. 2 sz. 65-66. oldal.;

[7.] Kállai Ernő: Víztisztítás a Magyar Honvédségben. http://www.sija.hu/wp-content/uploads/2012/04/kallai_ erno_viztisztatas_a_magyar_honvedsegben.pdf

[8.]http://www.gvh.hu/akadalymentes/IMPORT/import-20140110_134637/en/resolutions/resolutions_of the_competition_council_old/4070_hu_vj-4620069.html; [9.] Melenyec János: A ZVTÁ múszaki leírása, kezelési és karbantartási utasítása. (Belső kiadvány.);

[10.] Az MVT-4 víztisztítóval összefüggő szabadalmak.

[10.1] Eljárás radioaktív szennyezések eltávolítására alkalmas amorf cirkónium-foszfát alapú szorbens előállítására. Lajstromszám: 173499 (1976. 04. 20.) Szabadalmas: Nehézvegyipari Kutató Intézet (Veszprém). Feltalálók: dr. Bálint Tiborné, dr. Borszéki János, Barcánfalvi Ferenc, dr. Demjén Zoltán, dr, Fóti György, Gerlei István, Juhász Zoltán, Kollár Judit, dr. Nagy Lajos György, Székely István, dr. Török Gábor;

[10.2] Eljárás és berendezés folyadékok, előnyösen felszíni vizek örvényregenerálásos szürésére. Lajstromszám: 180028 (1978. 02. 17.) Szabadalmas: Nehézvegyipari Kutató Intézet (Veszprém). Feltalálók: dr. Pernyeszi József, Gerlei István, Juhász Zoltán, dr. Vasvári Vilmos;

[10.3] Hordozható berendezés különböző szennyezettségű, főleg felszíni vizek ivóvíz nyerése céljából történő tisztítására. Lajstromszám: 188999 (1983. 11. 10.) Szabadalmas: Nehézvegyipari Kutató Intézet (Veszprém), Vízgépészeti Vállalat (Lajosmizse). Feltalálók: Babóczky Ervin, Bagi László, dr. Maier Ferenc, dr. Pernyeszi József, dr. Vasvári Vilmos, Gerlei István, Gonda Gyula, Juhász Zoltán, Melenyec János, Papp Mihály, Tillinger Ferenc, Vodál Árpád;

[10.4] Eljárás aktívszén alapú, savas karakterű, oxidált szorbensek előállítására. Szabadalmas: Nehézvegyipari Kutató Intézet (Veszprém, 1982. 09. 29.) Feltalálók: dr. Pernyeszi József, dr. Maier Ferenc, Bagi László, Gerlei István, Juhász Zoltán;

[11.] http://autofer.hu/tartalom/katonai_ jarmufelepitmenyek/.

1 1981-től Ipari Minisztérium, amely a Kohó és Gépipari Minisztérium, a Könnyüipari Minisztérium és a Nehézipari Minisztérium összevonásával jött létre. A hadiipari feladatokat kezdetben az Általános Szervezési Főosztály látta el, amely később az Iparszervezési Főosztály nevet kapta.

2 A csapatpróbákat megelőző haditechnikai ellenőrző vizsgálatok (ht. ell. vizsgálatok) a HMK teljesítettségének az ellenőrzésére szolgáltak, és az

4 A konténerszerű felépítmény (KF) család tagjai (KF-1, KF-2, KF-3;) váltották az egységes, zárt (EZF) felépítményeket a tárgyalt időszakban. 5 EFE TT = az Egyesített Fegyveres Erők Tudományos Tanácsa, többek között az EHMK-k és az EVM-ek jóváhagyója. 